\title{
Modeling and Performance Evaluation of Standalone Solid Oxide Fuel Cell for Aircraft APU- II: Dynamic Performance
}

\author{
Golnaz Pourabedin *, Fatholah Ommi *** \\ * Department of Mechanical Engineering, Aerospace Faculty, Tarbiat Modares University, Tehran, Iran. \\ ** Department of Mechanical Engineering, Aerospace Faculty, Tarbiat Modares University, Tehran, Iran. \\ (golnaz_pourabedin@yahoo.com,fommi@modares.ac.ir) \\ ¥Corresponding Author; Fatholah Ommi, Postal Cod:1411713116, Tel: +98 21 82883948, Fax: +98 21 88269296, \\ fommi@modares.ac.ir
}

Received: 30.12 .2018 Accepted:17.02.2019

\begin{abstract}
The analysis of fuel cells can be divided into two areas, steady state modelling, and dynamic modelling. Our prior paper [1] focused on the steady-state performance of anode-supported jet fuel external reforming planar solid oxide fuel cell stack model for aircraft Auxiliary Power Unit (APU) application. The aim of the current paper is to evaluate the transient behavior of this solid oxide fuel cell system to sudden electric load changes. The present model solves transient mass, energy, and electrochemical equations for a solid oxide fuel cell (SOFC) and calculates time responses of output parameters of the system by a step change of the electric current. In this model, some important capacitive elements in the fuel cell process are modelled. The focus of this study is on application to "more-electric" airplanes and the regional jet used as a case study. SOFC system heat-up stage and the output voltage response to a sudden load change at small, medium and large timescales are presented in this paper. Results indicate that the electric characteristics be adapted to new conditions of SOFC sooner than the state parameters.
\end{abstract}

Keywords Solid Oxide Fuel cell; Aircraft APU; Dynamic Modeling; Current load; Simulink.

\section{Introduction}

Electricity generation from fossil fuels produces low efficiency and high pollution. In aircrafts, the weight and volume of the system are very important. A solid oxide fuel cell is a good solution for power generation in aircraft to increase efficiency and reduce pollutants. Especially, the emissions from the SOFCs are known to be the lowest for an all of the fossil fuels [2]. The SOFC APU has high efficiency, low emission and can produce high power therefore this technology is very interested for researchers [3].

In order to reduce costs, increase reliability and increase the SOFC lifetime, the dynamic study of fuel cell is of great importance. A lot of research has been done on SOFC APU modeling but most of them are steady state and feasibility study. [4-8]. In [13] the steady-state performance analysis and the exergetic analysis of a Jet-A fueled hybrid SOFC/GT system with a power output of 250 is analyzed. In [4] the performance of various hybrid SOFC-APU system architectures is compared against an advanced gas turbinebased APU system. In addition to the merits of different system architectures, optimal SOFC system parameter selection is discussed. In [14] two models have been developed based on simple thermodynamic expressions. As a result, FC performance was a strong function of the operating temperature.

Paper [15] presents a comprehensive review of the possible layout configurations of hybrid power plants based on the integration of solid oxide fuel cells (SOFC) and gas turbine (GT) technologies. The paper also presents a review of hybrid SOFC/GT power plants fed by alternative fuels, such as coal and biomass and Estimates the weight values of all components involved in the system.

In Reference [16] use of bi-directional Solid-Oxide Cells (SOC) as auxiliary power unit (APU) on-board commercial aircraft is explored. This work focusses on use of these bi- 
directional SOCs as fuel cells during flight operations and as electrolyzes to produce sustainable fuel at the airport when the aircrafts are parked.

In [17] Gas Turbine - Solid Oxide Fuel Cell (GT-SOFC) Aircraft Auxiliary Power Unit (APU) configuration is thermodynamically investigated. As a result, Hybrid system weigh is twice as much as the conventional APU but has lower fuel consumption.

Finally reference [18] reviews the SOFC-APU systems for aircraft. This review brings together publications in the form of articles, reports, theses and patents related to the use of solid oxide fuel cells in aircraft with a focus on replacing the current auxiliary units with a hybrid system. The potential advantages and main challenges of the new technology are reported, indicating some possible trends in this technology.

In this paper, we modelled dynamic behavior of a standalone SOFC unit fueled by hydrogen that achieved from jet fuel reforming for airplane APU applications.

\section{Model Description}

Mathematical modeling is an effective method for evaluating SOFCs in steady state. Evaluating the performance of Planar SOFC in transient behavior is the goal of current paper. The results of modeling in steady state have already been presented in [1]. In this paper, only a brief summary of the mathematical model is presented and for further study refer to [1].

Mass transport, temperature, and flow rates are calculated via conservation equations. Ions transport to TPB is evaluated via gas diffusion equations. The charge transfer kinetics governs the electrochemistry reactions at the TPB.

The transient phenomena and the dynamic model equations for each one are provided in this section.

\subsection{Internal Impedance}

The ohmic, activation and concentration polarization is evaluated for electrochemical analysis. The cell voltage is calculated via equation (1).

$\mathrm{V}_{\text {cell }}=\mathrm{E}_{\text {cell }}-\mathrm{V}_{\text {activation,cell }}-\mathrm{V}_{\text {ohmic,cell }}-\mathrm{V}_{\text {concentration,cel }}$

The more details equations of the electrochemistry model through the ideal gas assumption are accessible in [1]. Equation (1) is a steady state equation that contains no dynamic parameter. In a solid oxide fuel cell, the two electrodes are separated by an electrolyte and form two double layers, which include the electrolyte-anode layer and the electrolyte-cathode layer. These layers are charged by the polarization effect, called the electrochemical double-layer charging effect during normal fuel cell operation [9]. These layers store electrical energy and act like a super capacitor. In this model, this effect is investigated and the corresponding dynamics is described by the equivalent circuit [9], [10] shown in Fig. 1. Because of the parallel R-C circuit, the net instantaneous current is the sum of current through both $\mathrm{R}$ and $\mathrm{C}$ elements [11]. Hence,

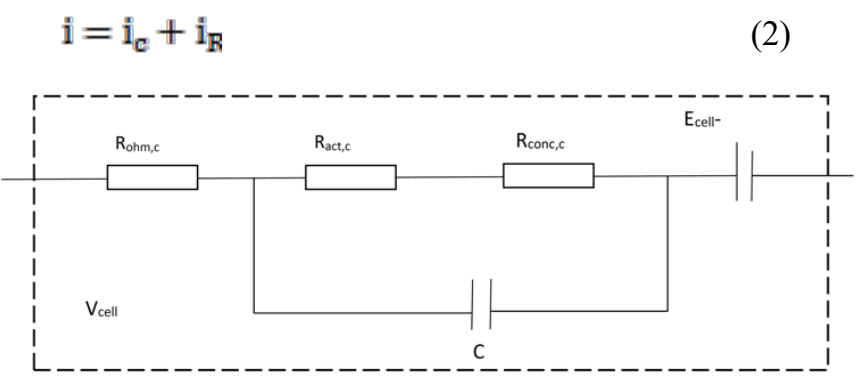

Fig. 1. Equivalent electrical circuit.

The current across the capacitor is defined as follows:

$\mathrm{i}_{\mathrm{c}}=\mathrm{C} \frac{\mathrm{dV_{ \textrm {CeeI } }}}{\mathrm{dt}}$

Therefore, the output voltage changes as follows:

$\mathrm{V}_{\text {cell }}=\mathrm{E}_{\text {cell }}-\mathrm{V}_{\mathrm{C}_{2} \text { cell }}-\mathrm{V}_{\text {act } 0_{2} \text { cell }}-\mathrm{V}_{\text {ohmicel }}$

Where $V_{\text {act } 0, c e l l}=\xi_{0}+\xi_{1} \mathrm{I}$ is depending on the fuel cell input temperature. $\mathrm{V}_{\mathrm{C} \text {,cell }}$ can be obtained as:

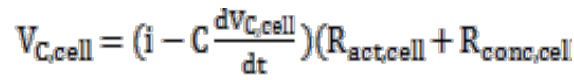

In an electrical circuit with a capacitor and a resistor the time constant can be defined as:

$\tau_{\mathrm{dl}}=\left(\mathrm{R}_{\text {activationcell }}+\mathrm{R}_{\text {Concentration,cell }}\right)($

Although the capacity (C) of the double layer charging effect due to porous electrodes is large (several Farads) [9], the time constant $\tau_{d}$ due to the small amount of ( $R_{\text {activation,cell }}+R_{\text {Concentrationcell }}$ ) is small in this study (small timescale).

\section{Reactant Electrode Transport}

The Stephan-Maxwell relationship for multi-species diffusion is $[11,12]$ :

$-n_{t} \frac{d x_{i}}{d x}=\frac{N_{i}^{d}}{D_{i}^{* k}}+\sum_{j=1}^{J}\left(\frac{X_{j} N_{i}^{d}-X_{i} N_{j}^{d}}{D_{i j}^{8}}\right.$

Although diffusion is a major obstacle to the passage of fuel in the electrodes, the thickness of the porous electrodes is short. Therefore, the diffusion dynamics is in order of millisecond. The following equation shows the transient nature of this phenomena [11]:

$\varepsilon \frac{\mathrm{dn}_{\mathrm{i}}}{\mathrm{dt}}=\frac{\mathrm{dN}_{\mathrm{i}}}{\mathrm{dx}}+\mathrm{R}_{\mathrm{j}}$

In this case (Reactant Electrode Transport) we can ignore the transient behaviour. 


\subsection{Gas Channel Energy and species Transport}

The main principles of SOFC modeling in the present model are mass and energy conservation. The continuity equations determined through the ideal gas assumption include the inlet and outlet flow rates and effective partial pressures of the component in channels due to the reactions:

$\frac{\mathrm{v}_{\mathrm{a}}}{\mathrm{RT}_{\mathrm{F}}} \frac{\mathrm{dP}}{\mathrm{dt}}=\left(\mathrm{n}_{\mathrm{in}, \mathrm{i}}-\dot{\mathrm{n}}_{\text {out } \mathrm{i}}\right)+\sum_{\mathrm{j}=0 \mathrm{x}} \mathrm{v}_{\mathrm{i}, \mathrm{j}} \mathrm{r}_{\mathrm{j}} \frac{1}{\mathrm{~A}_{\mathrm{a}}} \quad \mathrm{i} \in\left\{\mathrm{H}_{2}, \mathrm{H}_{2} \mathrm{O}\right\}$

$\frac{v_{c}}{\operatorname{RT}_{A}} \frac{d \dot{p}}{d t}=\left(n_{\text {in,i }}-\dot{n}_{\text {out }, i}\right)+v_{i, \text { Red }} r_{\text {Red }} \frac{1}{A_{c}} \quad i \in\left\{N_{2}, O_{2}\right\}$

From the Laplace form of the above equations, the time constant for the cathode and anode is obtained:

$$
\tau_{\mathrm{a}}=\frac{\mathrm{v}_{\mathrm{a}} \mathrm{P}_{\mathrm{a}}^{\mathrm{ch}}}{\left.2 \mathrm{n}_{\mathrm{a}} \mathrm{R}\right]} \quad \tau_{\mathrm{c}}=\frac{\mathrm{v}_{\mathrm{c}} \mathrm{P}_{\mathrm{c}}^{\mathrm{ck}}}{\left.2 \mathrm{n}_{\mathrm{c}} \mathrm{R}\right]}
$$

The mass transfer dynamic in flow channels depends on the stack geometry. For the model parameters used in this study, the time constants are in the range of several seconds.

As described in [1], five layers of temperatures (fuel and air channels, PEN and air and fuel interconnectors) and radiation between solid parts are considered in energy balance equations. The energy balance equations through the lumped temperature assumption are:

$\dot{q}_{\text {chem }}-\dot{q}_{\text {elec }}-\dot{q}_{\text {convair }}+\dot{q}_{\text {conv,fuel }}+\dot{q}_{\text {air,flow }}+\dot{q}_{\text {fuel,flow }}+\dot{q}_{\text {Rad,IA }}+\dot{q}_{\text {Rad,IF }}$
$=m_{\text {pEN }} C_{\mathrm{pEN}} \frac{\mathrm{dT}_{\mathrm{PEN}}}{\mathrm{dt}}$

$$
\begin{aligned}
& \dot{q}_{\text {convfuel }}+\dot{q}_{\text {fuel,flow }}-\dot{q}_{\text {fuel,flow }}=m_{\text {fuel }} \mathrm{C}_{\text {fuel }} \frac{\mathrm{dT}_{\mathrm{F}}}{\mathrm{dt}} \\
& \dot{q}_{\text {convair }}+\dot{q}_{\text {airflow }}-\dot{q}_{\text {air,flow }}=\mathrm{m}_{\text {air }} \mathrm{C}_{\text {air }} \frac{\mathrm{dT}_{\mathrm{f}}}{\mathrm{dt}} \\
& \dot{q}_{\text {Rad,IF }}-\dot{q}_{\text {fuel,flow }}=\mathrm{m}_{\mathrm{IF}} \mathrm{C}_{\mathrm{IF}} \frac{\mathrm{dT}_{\mathrm{IF}}}{\mathrm{dt}}
\end{aligned}
$$$$
\dot{q}_{\text {Rad }, I A}-\dot{q}_{\text {air,flow }}=m_{\mathrm{IA}} \mathrm{C}_{\mathrm{IA}} \frac{\mathrm{dT}_{\mathrm{IA}}}{\mathrm{dt}}
$$

The thermal time constant through the lumped temperature assumption in Convection existence defined $\tau_{\mathrm{t}}=\frac{\text { (mPENCPEN }}{\text { (hPENAPEN) }}$

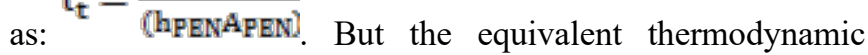
time constant of an SOFC for overall thermal equation can be of the order of $10^{2}-10^{3} \mathrm{~s}$ (large timescale).

\section{Results and Discussion}

In this paper, the suggested NASA regional jet APU was used as a case study [5]. The SOFC is based on the Gen3 Delphi planar SOFC characteristics. The model of the Solid Oxide Fuel Cell stack has been developed and implemented by the authors in the MATLAB SIMULINK, as described in [1]. The parameter's value of ER-SOFC system for this simulation study is listed in Table 1.

Table 1. The parameter's value of ER-SOFC system

\begin{tabular}{|l|l|l|}
\hline Parameters & Value & unit \\
\hline Anode thickness & $510^{*} 10^{-6}$ & $\mathrm{~m}$ \\
\hline Cathode thickness & $34^{*} 10^{-6}$ & $\mathrm{~m}$ \\
\hline Electrolyte thickness & $10^{*} 10^{-6}$ & $\mathrm{~m}$ \\
\hline Interconnector thickness & $500^{*} 10^{-6}$ & $\mathrm{~m}$ \\
\hline effective Nusselt number in the air channel & 5 & - \\
\hline effective Nusselt number in fuel channel & 3.6 & - \\
\hline Interconnectors Emissivity Coefficient & 0.9 & - \\
\hline Anode Specific heat capacity & 466 & $\mathrm{~J} / \mathrm{kg} \mathrm{K}^{-6}$ \\
\hline Cathode Specific heat capacity & 520 & $\mathrm{~J} / \mathrm{kg} * \mathrm{~K}$ \\
\hline Gen 3 SOFC Stack characteristics & & \\
\hline Parameter & Values & unit \\
\hline Number of cells & 30 cell per stack & - \\
\hline active area & 105 & 13 \\
\hline 30 cell Stack weight & 3.5 & $\mathrm{~km} 2$ \\
\hline 30 cell Stack volume & litter \\
\hline
\end{tabular}


In this part, the cell transient responses for several load changes are considered. As a control strategy, the fuel mass flow rate is considered constant. But the fuel utilization parameter changes by changing of electric charge.

The time constant $(\tau)$ is a very important parameter in the dynamic behaviour studies, which is the time it takes for a system to respond to changes.

Different timescales are:

the small time scale in the order of $10^{-5}-10^{-1} \mathrm{~s}$ caused by electrochemical conversion $\left(\tau_{\mathrm{dl}}\right)$ the medium time scale in the order of $10^{0}-10^{1} \mathrm{~s}$ caused by mass and species transport $\left(\tau_{\mathrm{a}}, \tau_{\mathrm{c}}\right)$

the large time scale in the order of $10^{2}-10^{3} \mathrm{~s}$ caused by energy $\operatorname{transport}\left(\tau_{t}\right)$

The fixed inlet condition at $1223 \mathrm{k}$ and $1 \mathrm{~atm}$ and pure $\mathrm{H} 2$ and air at the anode and cathode inlet are assumed. The operating conditions of the SOFC model for this simulation study are listed in Table 2.

Table 2. The operating conditions of ER-SOFC system model

\begin{tabular}{|l|l|}
\hline Test parameters & Value \\
\hline mole flow rate (mole/s) & 0.1 \\
\hline Pressure (atm) & 3 \\
\hline Temperature (k) & 1223 \\
\hline STCR & 2.5 \\
\hline OTCR & 0.7 \\
\hline Landa (excess air) & 8 \\
\hline H2 flow rate (mole/s) & $62^{*} 10^{-4}$ \\
\hline H2O flow rate (mole/s) & $36^{*} 10^{-4}$ \\
\hline Air flow rate (mole/s) & $796^{*} 10^{-4}$ \\
\hline
\end{tabular}

Table 3. SOFC APU current demand

\begin{tabular}{|l|l|l|l|c|}
\hline Parameter description & Gate & MES (185.3kw) & Cruise (84.3kw) & $\begin{array}{c}\text { Cruise EO } \\
(124.1 \mathrm{kw})\end{array}$ \\
\hline SOFC current demand (A) & 164.3 & 268.6 & 97.8 & 139.3 \\
\hline
\end{tabular}

Table 3 represents an estimated Regional Jet mission load profile, based on More-Electric Aircraft (MEA) architecture [5].

The initial condition is the steady state condition for zero electric current. At time $\mathrm{t}=0$ the load current on the SOFC is increased from $0 \mathrm{~A}$ to $164 \mathrm{~A}$ (step1- Gate). Then the load current is increased from 164A to 268A (step2MES) and finally the load current is decreased from 268A to $140 \mathrm{~A}$ (step3- Cruise).

\subsection{Small timescale}

As described in section 2, for a small time scale, the double-layer charging effect is dominated at the dynamic response of the model.

Figure 2,3,4 show the model dynamic responses in the small timescale under step-load current changes. The load current steps up from 0 to $164 \mathrm{~A}$ at $0.05 \mathrm{~s}$. Then steps up to $268 \mathrm{~A}$ in $0.15 \mathrm{~s}$, finally steps down to $140 \mathrm{~A}$ at $0.2 \mathrm{~s}$.

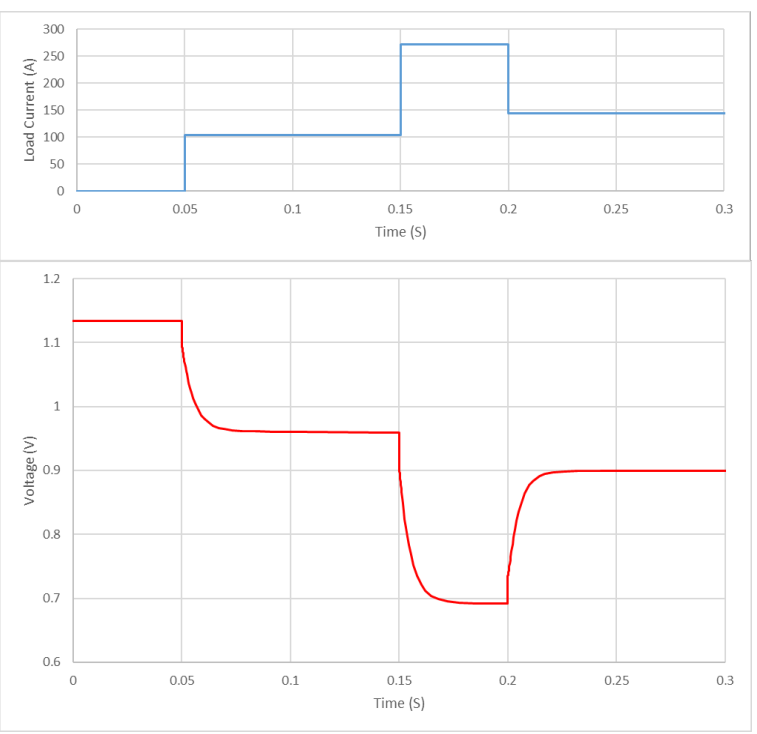

Fig. 2. Dynamic responses of SOFC voltage versus time in small time scale. 
Figure 2 shows the SOFC voltage versus time. When the current load increases (step 1 and 2), the fuel cell output voltage decreases suddenly because of the ohmic voltage drop, and then decreases slowly toward its final value (Second steady state).

Figure (3) shows the time scale of three distinct processes in the third step. The first, $V_{\text {Ro }}$, is the sudden response of the SOFC voltage due to pure resistive elements inside the fuel cell. The second, relatively fast, $V_{\text {Rct }}$ process is due to the time it takes a charge transfer process at the electrode-electrolyte interface to respond to the change in load. Eventually, the relatively slow response of $V_{p}$ occurs as a result of the time it takes the reactant concentrations to change. These three processes occur during the fuel cell operation and with any change in electric load (figure 4).

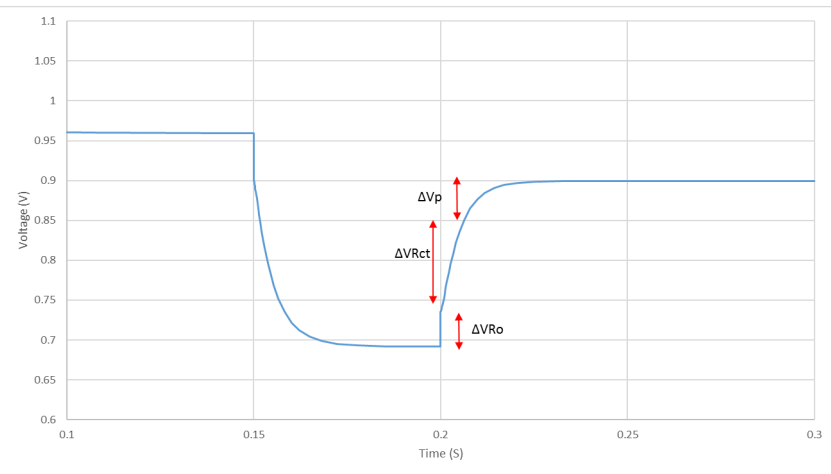

Fig. 3. Three separate sections of the dynamic response at a small time scale
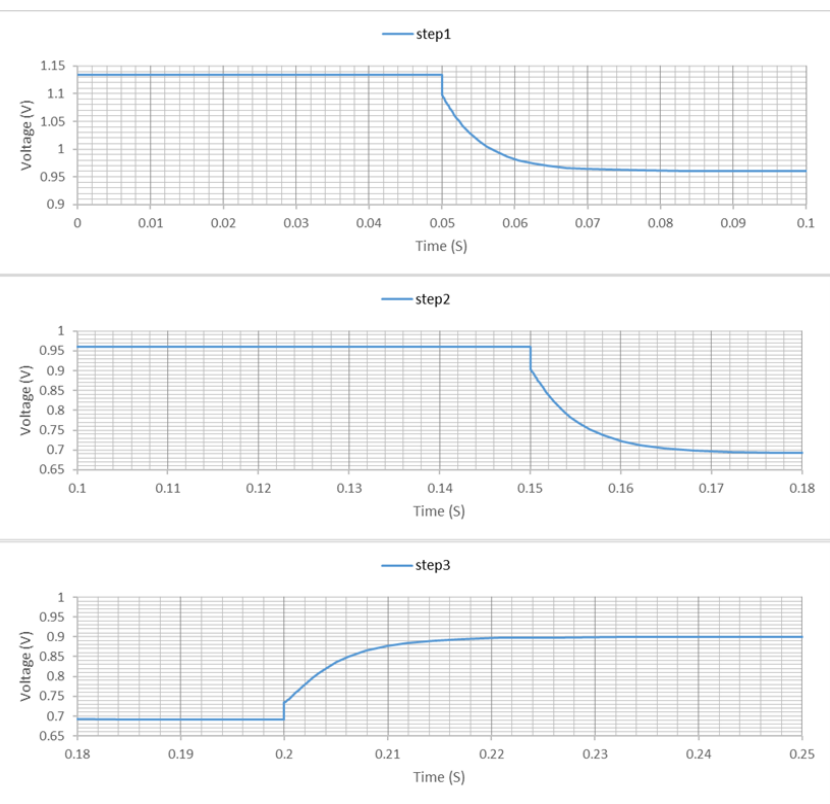

Fig. 4. Dynamic responses of SOFC voltage versus time in three distinct steps

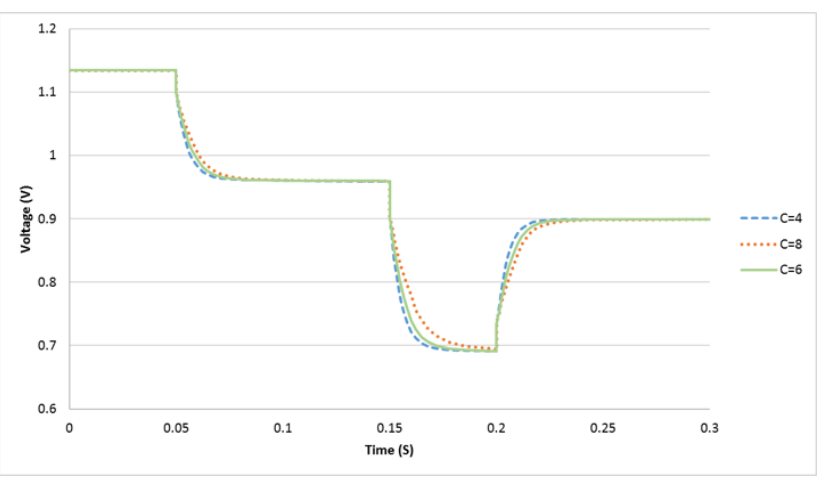

Fig. 5. SOFC output voltage versus time by changing double layer charging capacity

Fig 5 shows the SOFC output voltage versus time by changing double layer charging capacity in small time scale. As the capacitance increases, the time constant increases and the voltage decreases slowly with a lower slope to the final value.

\subsection{Medium timescale}

Fig 6 and 7 show dynamic responses of SOFC voltage versus time in medium time scale for three different loads current change. The load current steps up from 0 to $164 \mathrm{~A}$ at $1 \mathrm{~s}$. Then steps up to $268 \mathrm{~A}$ in $7 \mathrm{~s}$, finally steps down to $140 \mathrm{~A}$ at $15 \mathrm{~s}$. by increasing load current in step 1 and step 2 , the voltage decreases respectively about 0.2 and 0.26 . Vice versa the voltage increases about 0.21 volt by decreasing load current in step 3.

Fig 8 shows the SOFC output voltage versus time in different operating pressures in medium time scale. By increasing the pressure, the time constant and voltage increase.

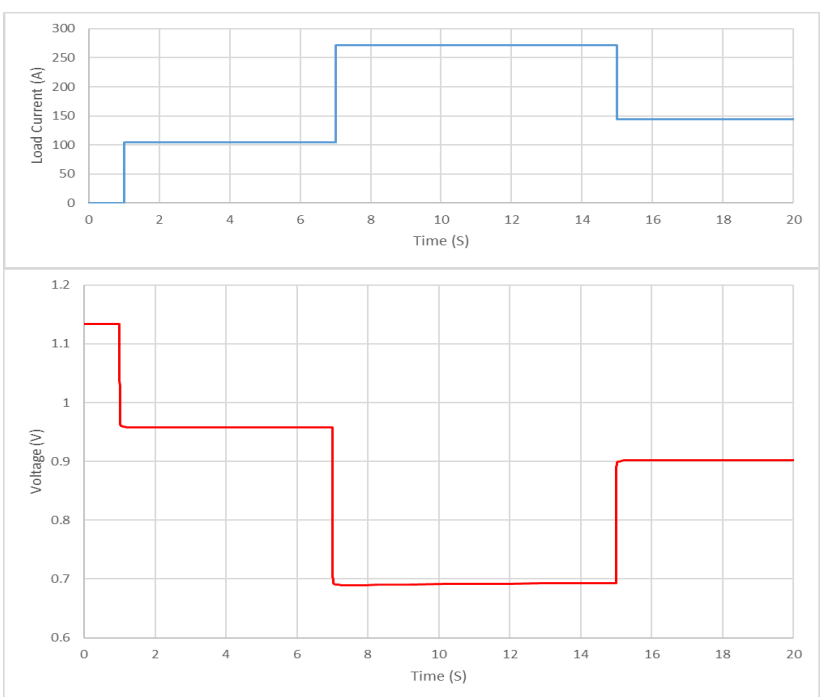

Fig. 6. Dynamic responses of SOFC voltage versus time in medium time scale 


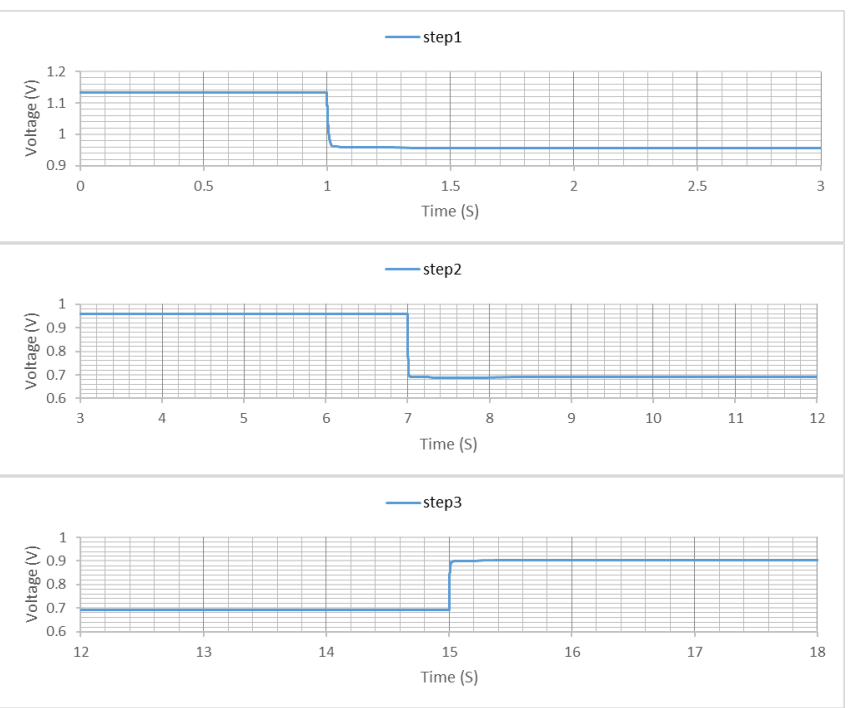

Fig. 7. Dynamic responses of SOFC voltage versus time in three distinct steps

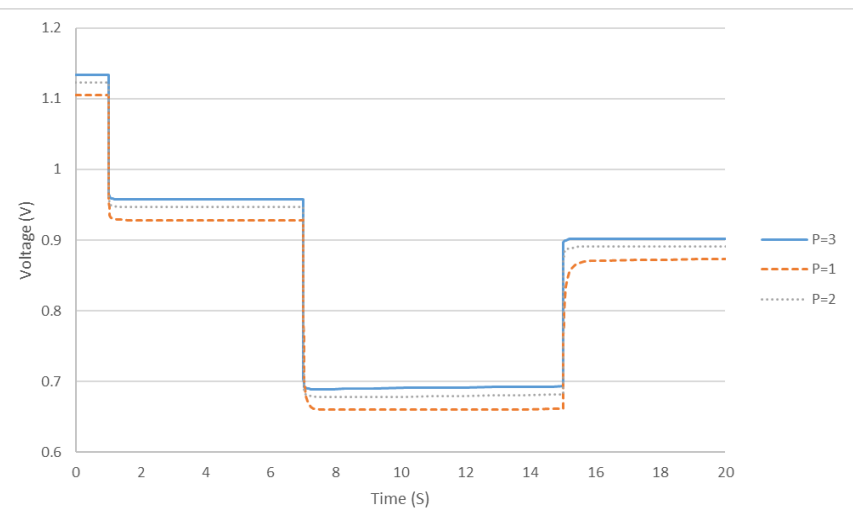

Fig. 8. SOFC output voltage versus time in different pressure

\subsection{Large timescale}

One of the most important SOFC behaviours considered today is thermal dynamics [11]. Thus, for the large timescale, the thermodynamic characteristics will dominate the model dynamic responses.
Figure 9 shows the transient response of the SOFC model under load changes. The steps change in the load current from 0 to $164 \mathrm{~A}$ at $100 \mathrm{~s}$. Then steps up to $268 \mathrm{~A}$ in $700 \mathrm{~s}$, finally steps down to $140 \mathrm{~A}$ at $1500 \mathrm{~s}$.

When the load current increases stepwise, the SOFC output voltage drops sharply and then rises to the final value (steps 1 and 2). By decreasing the load current, the output voltage suddenly increases and then slowly reaches its final value (step 3).

As can be seen in Fig. 9, there is a sudden bursting down below the new steady state for cell voltage in steps 1 and 2 , and a sudden climb in step 3 . These sudden changes are due to the slow thermal response of the SOFC materials [5].
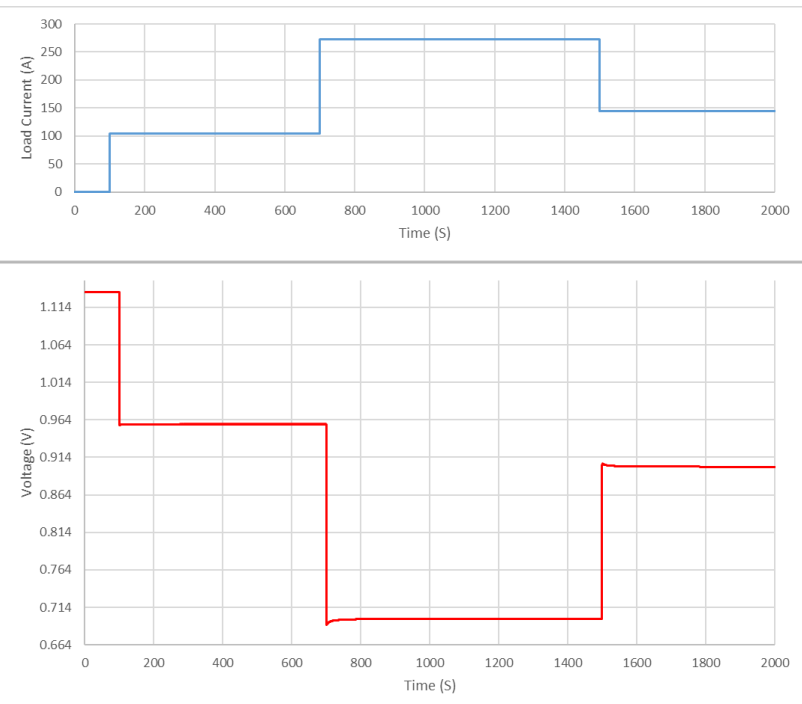

Fig. 9. Dynamic responses of SOFC voltage versus time in large time scale
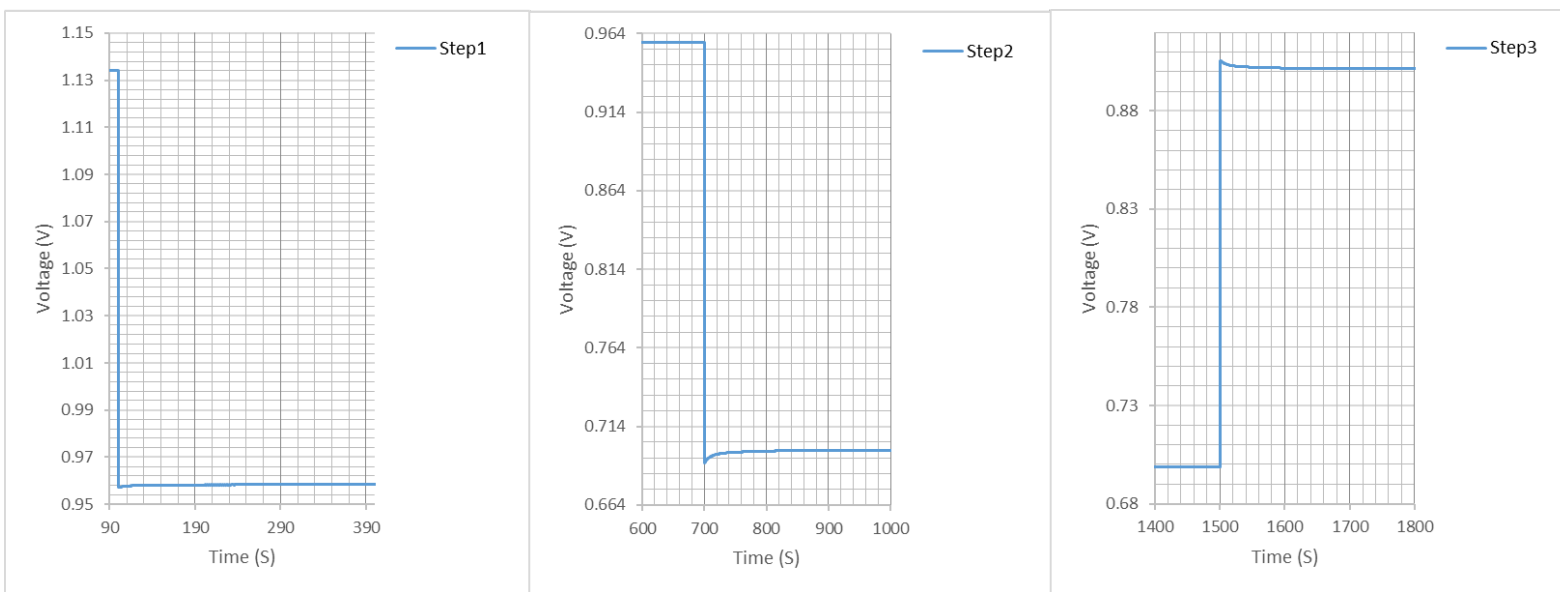

Fig. 10. The time between two steady state conditions 
As can be seen in figure 10, the voltage reaches their new steady state condition by approximately after 134, 548 and $306 \mathrm{~s}$. By increasing the step change, the time between two steady state conditions was decreased.

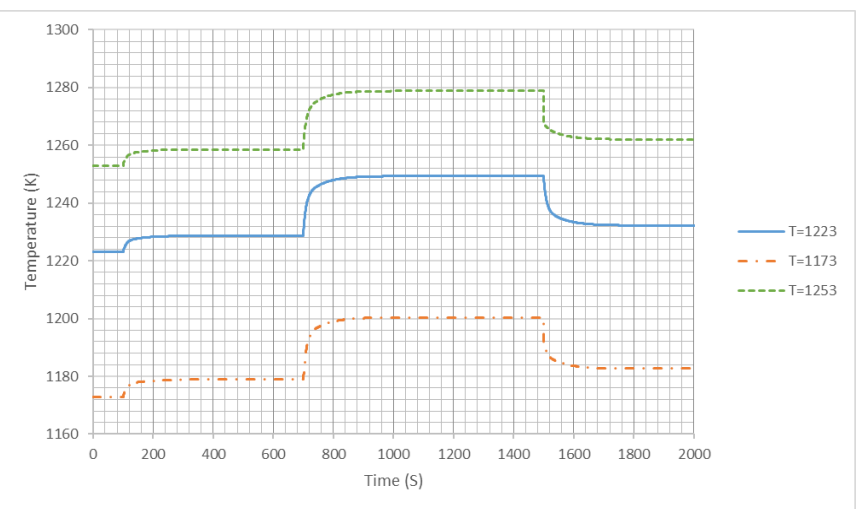

Fig. 11. SOFC model temperature versus time in different inlet temperature in large timescale

Figure 11 shows the temperature response of the SOFC model at different input temperatures in a large time scale. As can be seen, the thermal conditions in the three different steps, approximately after 460, 525 and 591 seconds, reach a new equilibrium. The temperature changes for the gas stream are about 6,20 and 17 Kelvin for steps 1 to 3 .

Comparing figures 10 and 11 shows that the time between two steady states in the voltage diagram is much less than the temperature graph (steps 1 and 3). Therefore, electrical characteristics will be coordinated much earlier than state parameters to new conditions.

\section{Conclusion}

In this paper, the dynamic modelling of a standalone SOFC auxiliary power unit for aircraft has evaluated. A dynamic model was presented for planar SOFC based on their electrochemical and thermodynamic properties. The model has been made in MATLAB Simulink. Dynamic characteristics of the model are given for constant fuel flow. The model dynamic responses are evaluated from a small timescale to a large timescale for three step changes from Ground Load to MES and finally to cruise.

The results show that by increasing the capacitance, the time constant increase and the voltage decreases slowly with a lower slope to the final value in small timescale but in medium timescale by increasing the pressure, the time constant and voltage increase. On the other hand, in large timescale, results show that by increasing the step change in voltage case, the time between two steady state conditions was decreased and electrical characteristics will be coordinated much earlier than state parameters to new conditions.

\section{References}

[1] Pourabedin G, Ommi F, Kazempour, P. Modeling and Performance Evaluation of Standalone Solid Oxide Fuel Cell for aircraft APU- I: model-based steady-state performance (Reforming efficacy). International Journal of Engineering \& Technology Sciences, Volume 03, Issue 06, Pages 393-407, 2015.

[2] Kopasakis, G. Brinson, T and Credle, S, Theoretical Solid Oxide Fuel Cell Model for System Controls and Stability Design, Journal of Fuel Cell Science and Technology, Volume 5, Issue 4, September 2088. doi:10.1115/1.2971018

[3] Lu N, Sun Q Li X, Khaleel M.A, The modeling of a standalone solid-oxide fuel cell auxiliary power unit, Journal of Power Sources, Volume 161, Issue 2, 27 October 2006, Pages 938-948. https://doi.org/10.1016/j.jpowsour.2006.05.009

[4] Braun R J, Gummalla M, Yamanis, J. system architectures for solid oxide fuel cell-based auxiliary power units in future commercial aircraft applications. Journal of Fuel Cell Science and Technology, Volume 6, Issue 3, May 2009. doi:10.1115/1.3008037

[5] Mak A, Meier J., Fuel Cell Auxiliary Power Study, NASA/CR-2007-214461-VOL1, E-15725, 21-13153, Feb. 2007. Document ID: 20070014605

[6] Tornabene R, Wang W Y, Steffen C J, Freeh Joshua E. Development of Parametric Mass and Volume Models for an Aerospace SOFC/Gas Turbine Hybrid System, ASME Turbo Expo 2005: Power for Land, Sea, and Air, Volume 5, Paper No. GT2005-68334, pp. 135-144, June 2005. doi:10.1115/GT2005-68334

[7] Freeh, J.E., Pratt, J.W., Brouwer, J., Development of a Solid-Oxide Fuel Cell/Gas Turbine Hybrid System Model for Aerospace Applications, ASME Turbo Expo 2004: Power for Land, Sea, and Air, Volume 7, Paper No. GT2004-53616, pp. 371-379; 9 pages. doi:10.1115/GT2004-53616

[8] Daggett, D., Eelman, S., and Kristiansson, G., (2003) "Fuel Cell APU for Commercial Aircraft," AIAA2003- 2660, AIAA International Air and Space Symposium and Exposition: The Next 100 Years, Dayton, $\mathrm{OH}, \mathrm{USA}$.

[9] Larminie J, Dicks A, "Fuel Cell Systems Explained", 2nd ed, New York, Wiley, 2003.

[10] Wang C, Nehrir M. H, Shaw S. R, Dynamic models and model validation for PEM fuel cells using electrical circuits, IEEE Trans. Energy Convers., vol. 20, no. 2, pp. 442-451, Jun. 2005.

[11] Bove R, Ubertini S, Modeling Solid Oxide Fuel CellsMethods, Procedures and Techniques, Fuel Cells and Hydrogen Energy, Springer, 2008. 
[12] Amphlett J. C, Baumert R. M, Mann R. F, Peppley B. A, Roberge P. R, Performance modeling of the Ballard Mark IV solid polymer electrolyte fuel cell, I: Mechanistic model development, J. Electrochem. Soc., vol. 142, no. 1, pp. 1-8, Jan. 1995.

[13] Sciubba E, Toro C, MODELLING AND SIMULATION OF A HYBRID SOFC/GT SYSTEM FOR AN AIRCRAFT AUXILIARY POWER UNIT, ASME-ATI-UIT 2010 Conference on Thermal and Environmental Issues in Energy Systems 16 - 19 May, 2010, Sorrento, Italy.

[14] Penyarat Chinda, Pascal Brault. The hybrid solid oxide fuel cell (SOFC) and gas turbine (GT) systemssteady state modeling. International Journal of Hydrogen Energy, Elsevier, 2012, 37, pp.92379248.<10.1016/j.ijhydene.2012.03.005

[15] Buonomano A, Calise F, d'Accadia MD, Palombo A, Vicidomini M. Hybrid solid oxide fuel cellsegas turbine systems for combined heat and power: a review. Appl Energy 2015;156:32e85.

[16] Fateh S. Bi-directional Solid Oxide Cells used as SOFC for Aircraft APU system and as SOEC to produce fuel at the airport Exergy evaluation of jet fuel and ammonia as fuel alternatives. Rotterdam, Nederlands: Faculty of Mechanical, Maritime and Materials Engineering-Delft University of Technology; 2015.

[17] Tunca F, Kaya N. Thermodynamic analysis of gas turbine solid oxide fuel cell (GT-SOFC) aircraft auxiliary power unit (APU). J Adv Mech Automob Engg 2017;4(1):10e4.

[18] Fernandes MD, et al., SOFC-APU systems for aircraft: A review, International Journal of Hydrogen Energy, 2018. 